Abstracta Iranica Abstracta Iranica

Revue bibliographique pour le domaine irano-aryen

Volume 22 | 2001

Comptes rendus des publications de 1999

\title{
Soleil du Réel [50ènes d'amour mystique. Traduction et présentation par Christian Jambet, Paris, Imprimerie Nationale Editions, 1999, 221 p.
}

\section{Pierre Lory}

\section{OpenEdition}

1 Journals

\section{Édition électronique}

URL : http://journals.openedition.org/abstractairanica/36862

DOI : 10.4000/abstractairanica.36862

ISSN : 1961-960X

Éditeur :

CNRS (UMR 7528 Mondes iraniens et indiens), Éditions de l'IFRI

\section{Édition imprimée}

Date de publication : 15 mai 2001

ISSN : 0240-8910

\section{Référence électronique}

Pierre Lory, «Soleil du Réel [⿷匚⿱⿰㇒一母: Poèmes d'amour mystique. Traduction et présentation par Christian Jambet, Paris, Imprimerie Nationale Editions, 1999, 221 p. », Abstracta Iranica [En ligne], Volume 22 I 2001, document 393, mis en ligne le 17 février 2010, consulté le 12 octobre 2020. URL : http:// journals.openedition.org/abstractairanica/36862 ; DOI : https://doi.org/10.4000/abstractairanica. 36862

Ce document a été généré automatiquement le 12 octobre 2020

Tous droits réservés 


\section{Soleil du Réel ${ }_{20}^{20}$ Poèmes d'amour} mystique. Traduction et présentation par Christian Jambet, Paris, Imprimerie Nationale Editions, 1999, $221 \mathrm{p}$.

\section{Pierre Lory}

C. Jambet nous offre ici un choix de cent poèmes extraits du Dīwān-i Šams-i Tabrīzi, traduits par ses soins avec un maniement consommé des ressources de la langue française qui font de ces textes des exemples fort réussis de ce qui peut être rendu de la poésie lyrique de Rūmī dès lors qu'on essaie d'y capter non pas seulement la ferveur émotionnelle, mais aussi l'ampleur métaphysique. La valeur de l'ouvrage est en outre rehaussée par la riche présentation (pp.7-55) où C.J. évoque notamment avec une netteté particulière la spiritualité de l'absence et de la théophanie de l'amour chez Mawlānā et la situe dans le courant de la pensée musulmane plus générale (Avicenne ; Sohravardī) et de la mystique (Ḥallāj; Rūzbehān); ce qui met d'ailleurs en valeur l'originalité de la vision de Rūmī.

\section{INDEX}

Thèmes : 8 . Soufisme 
AUTEURS

PIERRE LORY

EPHE - Paris 